University of Michigan Law School

University of Michigan Law School Scholarship Repository

1984

\title{
Miranda: The Case, the Man, and the Players
}

\author{
Yale Kamisar \\ University of Michigan Law School, ykamisar@umich.edu
}

Available at: https://repository.law.umich.edu/reviews/26

Follow this and additional works at: https://repository.law.umich.edu/reviews

Part of the Criminal Procedure Commons, Legal History Commons, and the Supreme Court of the United States Commons

\section{Recommended Citation}

Kamisar, Yale. "Miranda: The Case, the Man, and the Players." Review of Miranda: Crime, Law and Politics, by L. Baker. Mich. L. Rev. 82 (1984): 1074-92.

This Review is brought to you for free and open access by the Faculty Scholarship at University of Michigan Law School Scholarship Repository. It has been accepted for inclusion in Reviews by an authorized administrator of University of Michigan Law School Scholarship Repository. For more information, please contact mlaw.repository@umich.edu. 


\title{
MIRANDA : THE CASE, THE MAN, AND THE PLAYERS
}

\author{
Yale Kamisar*
}

MIRANDA: CRIME, LAW AND Politics. By Liva Baker. New York: Atheneum. 1983. Pp. 463. \$22.95.

On the eve of America's bicentennial, the American Bar Association told its members of a plan to publish a book about the "milestone events" in 200 years of American legal history, and invited them to vote on the milestones to be included. When the balloting was over, Miranda v. Arizona ${ }^{1}$ — "the high-water mark" of the Warren Court's revolution in American criminal procedure ${ }^{2}-$ had received the fourth highest number of votes. ${ }^{3}$ I venture to say that if members of the general public had been asked to list the "most regrettable" or "most unfortunate" milestones in American legal history, Miranda might have finished even higher in the voting. To many Miranda was "the red flag of Warren Court liberalism."4 The case "plunge[d] the Court into an ocean of abuse" and made it "one of the leading issues of the 1968 Presidential campaign."5

Somebody was bound to write a history of this epochal case, and now, in Miranda: Crime, Law and Politics, Liva Baker has written a book that is massive and exhaustively researched, yet thoughtful and readable. Although this review concentrates on what Baker has to say about Miranda, its ancestry, and its progeny, her book is much more than a book about Miranda the case and Miranda the man and

* Henry K. Ransom Professor of Law, University of Michigan. A.B. 1950, New York University; LL.B. 1954, Columbia University. Professor Kamisar's books include Police INTERROGATION AND CONFESSIONS (1980) and the annual ThE SUPREME CoURT: TRENDS AND DEVElopments (with Jesse Choper and Laurence Tribe). - Ed.

1. 384 U.S. 436 (1966). Actually, the Miranda opinion is an opinion for Miranda and three companion cases.

2. F. Graham, The Self-Inflicted Wound 157 (1970).

3. See J. Lieberman, Milestones- 200 Years of American Law vii (1976) (Publisher's Foreword). Marbury v. Madison, 5 U.S. (1 Cranch) 137 (1803); Chief Justice Warren and the Warren Court; and United States v. Nixon, 418 U.S. 683 (1974), finished first, second, and third respectively. Miranda edged out Brown v. Board of Educ., 347 U.S. 483 (1954), for fourth place and finished well ahead of Gideon v. Wainwright, 372 U.S. 335 (1963) (thirteenth place) and Mapp v. Ohio, 367 U.S. 643 (1961) (sixteenth place).

4. J. Grossman \& R. Wells, Constitutional LaW and Judicial Policy Making 883 (2d ed. 1980). See also, H. ABRAHAM, FREEDOM AND THE COURT 125 (4th ed. 1982) (Miranda "must rank as the most bitterly criticized, most contentious, and most diversely analyzed criminal procedure decision by the Warren Court.").

5. J. LIEBERMAN, supra note 3, at 326. 
how they fared. It is also a book 6 about the Supreme Court, the rights of the accused, the "politics of crime," and the social and political history of the 1960's and 1970's. Thus, it is also a book about Earl Warren, Warren Burger, Hugo Black, William Brennan, William Douglas, Abe Fortas, Richard Nixon, George Wallace, John McClellan, James Eastland, and many others. I found it more interesting reading, and much more rewarding, than The Brethren.7

The story of Miranda the case and Miranda the man is told in great detail and told well. For me, however, the least satisfying part of the book is Baker's discussion of the post-Miranda confession cases. ${ }^{8}$ Although she obviously has learned a great deal about the Supreme Court and about criminal. law and its administration, Baker is not a lawyer. And lawyers, especially law professors, are trained to attack lay persons' analyses of cases 'the way hounds attack foxes."9

The first half of Baker's Miranda is largely concerned with the fast-moving events that reshaped the law of confessions in the 1960's. On reading the book one is struck by just how rapid the pace of events was back then. Ernest Miranda was arrested on the morning of March 13, 1963, and he confessed that afternoon to the rape and kidnapping for which he was subsequently convicted (pp. 12-14). That was just five days before the United States Supreme Court finished some "old business" by ruling, in Gideon, ${ }^{10}$ that the sixth amendment's guarantee of counsel was fully applicable to the states. Miranda's lawyer filed his brief in the Arizona Supreme Court only one month after the U.S. Supreme Court had agreed to hear the Escobedo case (pp. 25, 31). ${ }^{1}$ (The U.S. Supreme Court moved much more quickly than the Arizona Supreme Court - almost a year before the state supreme court affirmed Miranda's conviction, the High Court handed down its decisions in Massiah ${ }^{12}$ and Esco-

6. Actually, Ms. Baker divides Miranda into four "books": Ernest Miranda's, Earl Warren's, Richard Nixon's and Warren Burger's. But each of these title personalities is so frequently discussed in all four "books" that I found it hard to remember which "book" I was reading.

7. B. Woodward \& S. Armstrong, The Brethren (1979).

8. This is only a small part of her book, but it is a large part of my review. See Part III infra.

9. Cf. Robbins v. California, 453 U.S. 420, 443 (1981) (Rehnquist, J., dissenting) (lawyers trained to attack "bright lines" in the law).

10. Gideon v. Wainwright, 372 U.S. 335 (1963). Incorporation of the right to counsel had been urged on the Court several times before and rejected. See e.g., Betts v. Brady, 316 U.S. 455, 474-75 (1942) (Black, J., dissenting, joined by Douglas and Murphy, JJ.). Betts was expressly overruled by Gideon. 372 U.S. at 345.

11. Escobedo v. Illinois, 378 U.S. 478 (1964).

12. Massiah v. United States, 377 U.S. 201 (1964). 
bedo.13) The great constitutional criminal procedure cases were crowding in on each other.

Massiah extended the sixth amendment right to counsel, traditionally applicable only in trial-type settings, to any attempt to elicit incriminating statements from a person under indictment. ${ }^{14}$ That same Term, a scant five weeks later, Escobedo further extended the right to counsel to the pre-indictment stage, that is, "when the process shifts from investigatory to accusatory - when its focus is on the accused and its purpose is to elicit a confession," 15 - or, it can be argued, when the process so shifts and one or more of the limiting facts mentioned in Escobedo are also present.

At some points Justice Goldberg's opinion for the Court in Escobedo rejects the arguments for an "effective interrogation opportunity" so emphatically that it promises (or threatens) to extinguish all police interrogation. At other places, however, the opinion seems limited to its particular facts (Escobedo had requested and been denied an opportunity to seek advice from retained counsel). Thus, as Baker observes (and, if anything, I think she understates the general reaction), the case "generated confusion as well as resentment" (p. 34). ${ }^{16}$ "What were law enforcement officers to do about an accused too ignorant to request counsel [as Danny Escobedo had], too poor to engage counsel [again, as Escobedo had], too overawed by the power of the state to assert what rights he or she possessed?" (p. 34).

The Court's answer to these questions were not likely to please law enforcement officials. As one young prosecutor commented at the 1965 conference of the National District Attorneys Association, as he looked out over the room where his fellow prosecutors were popping champagne corks while they chatted about the Escobedo case: "Paris just before the Maginot Line collapsed must have been a little like this" (p. 89).

The following year, of course, Miranda provided the answers that the police and prosecutors did not want to hear. But Miranda was not simply a better (or worse, depending on one's viewpoint) Escobedo. By shifting from the "focal point" - "accusatory state" test(s) to a "custodial interrogation" standard, and by moving from a rationale grounded in the sixth amendment right to counsel to one grounded in the fifth amendment privilege against self-incrimination, Miranda did not enlarge Escobedo as much as it displaced it.

13. Escobedo v. Illinois, 378 U.S. 478 (1964).

14. Massiah, 377 U.S. at 206. See Enker \& Elsen, Counsel for the Suspect: Massiah v. United States and Escobedo v. Illinois, 49 MiNN. L. REv. 47, 48 (1964).

15. 378 U.S. at 492.

16. For a summary of the wide disagreement over the probable meaning of Escobedo and over what it ought to mean - see Y. KaMISAR, PoLICE INTERROGATION AND CONFESSIONS: ESSAYS IN LAW AND POLICY 161-62 n.26 (1980) [hereinafter cited as KAMISAR Essays]. 
Massiah, however, continued to have independent significance; it operates once adversary judicial proceedings have begun, regardless of whether the suspect is being subjected to "custodial interrogation."17

Although one would gain little inkling of this from the hue and cry that greeted the case, Miranda may fairly be viewed as a compromise between the old "voluntariness"- "totality of the circumstances" test (a standard so elusive and unruly that its safeguards were largely illusory) and extreme proposals, based on an expansive reading of Escobedo, that threatened (or promised) to "kill" confessions. Miranda did not, and was not designed to, put an end to confessions. It allows the police to conduct "general on-the-scene questioning" even though the person questioned is both uninformed of and unaware of his rights. It allows the police to question a person in his home or office, provided they do not restrict the person's freedom to terminate the meeting. ${ }^{18}$ Moreover, "custody" alone does not require the Miranda warnings. The Court might have held that the inherent pressures and anxieties produced by arrest and detention and nothing more are substantial enough to require neutralizing warnings. But it did not do so.

It is the impact on the suspect of the interplay between police interrogation and police custody - each condition reinforcing the pressures and anxieties produced by the other - that, as the $M i$ randa Court correctly discerned, makes "custodial police interrogation" so coercive. It is the combination of "custody" and "interrogation" that establishes the "interrogation environment" that is "at odds" with the privilege against self-incrimination and that calls for "adequate protective devices." 19 Thus, so long as the police do not question one who has been brought, or is being taken, to the station house, Miranda permits them to hear and act upon "volunteered" statements, even though the "volunteer" neither knows nor is advised of his rights.

On the eve of Miranda, many doubted that law enforcement could survive if the Court were to project defense counsel into the police station (pp. 157-59). But the Miranda Court did so only in a quite limited way. Miranda's "major" "inherent weakness" (p. 407) - others would say its "saving grace" - is that it does not require that a suspect first consult with a lawyer, or actually have a lawyer present, in order for his waiver of constitutional rights to be deemed valid.

17. See note 44 infra and accompanying text.

18. One might even say that the Miranda opinion "recommends" that the police question a suspect in his house or place of business. See 384 U.S. at 477-78 \& n.46. 195-97.

19. See Miranda, 384 U.S. at 455-58. See generally KaMISAR EsSAYs, supra note 16, at 
"It was perhaps as a symbol" says Baker, "that Miranda had the most salutary impact" (p. 407). However perfunctorily read, the Miranda warnings served a "civilizing purpose" - they "remind[ed] the officer of the law that however miserable the one who stood before him, however savage the crime of which he was accused, he was still a man, possessed of all the attributes, including the constitutional rights, of other men" (p. 407).

The second half of Baker's book deals with, among other things, Richard Nixon's election to the presidency, the ascent of Warren Burger to the chief justiceship, the pervasive fear of crime and its exploitation by various politicians - Nixon's law-and-order speeches were "no less emotional, no less simplistic, no less grounded in fear than George Wallace's" (p. 245) - and, of course, Miranda's struggle to survive in the face of a hostile Congress and a hostile President. When Nixon made his third and fourth appointments to the Supreme Court Miranda "appeared doomed" (p. 324), but at the time Baker's book went to press "Miranda was not dead yet. . . . Not by a long shot" (p. 389).

Miranda the man was to meet a crueler fate - in January of 1976, after a fistfight over a poker game, he was stabbed to death. The killer fled, but his accomplice was caught. Before taking him to police headquarters, two Phoenix police officers read the suspect his rights - once in English, and once in Spanish - from a Miranda card (pp. 408-09).

So Baker's book ends. Hollywood, can you top this?20

\section{II}

Having made a living for a number of years largely through teaching, writing and speaking about police interrogation and confessions in general, and Miranda in particular, I thought I knew all there was to know about the case and those involved in it. I was mistaken. On reading Baker's book I learned, among other things, that:

- Alvin Moore, Miranda's court-appointed lawyer in the Ari-

20. Because Earl Warren was the author of the Miranda opinion, and Richard Nixon was its most vociferous critic, and Baker devotes so much of her book to their criss-crossing careers, one might say that her book has another ending: On the evening of July 9, 1974, only a day after the Supreme Court had heard oral arguments in United States v. Nixon, 418 U.S. 683 (1974), Earl Warren died - "never to know the outcome of [the Nixon] case, perhaps the most passionately felt of all." P. 372. Hollywood might like this ending too, but B. WOODWARD \& S. ARMSTRONG, supra note 7, at 312, and B. SCHWARTZ, SUPER CHIEF 771-72 (1983), provide a happier one.

According to these authors, Justice Brennan visited his old Chief only several hours before Warren's death and told him that Nixon had lost and the conference vote that morning had been unanimous. Warren is said to have responded: "Thank God-Thank God- Thank God-. . . . If you don't do it this way Bill, it's the end of the country as we have known it." B. SchWARTZ, supra, at 772. 
zona courts, "attended" LaSalle University School of Law, a Chicago-based correspondence school (pp. 17-18). ${ }^{21}$ Moore received only $\$ 100$ from Maricopa County for defending Miranda in Superior Court and another $\$ 100$ for the appeal to the Arizona Supreme Court (p. 18). But even a munificent fee would not have overcome his strong distaste for representing a kidnapping-rape defendant at this late stage in his legal career. He compared his task to that of a doctor "operating for locked bowels" (pp. 20, 83-84) — somebody had to do it. Only Moore's sense of duty had led him, at the age of seventy-three, to accept court appointments in criminal cases. $\mathrm{He}$ had added his name to the Superior Court's list of available attorneys only a month before being appointed Miranda's lawyer because a strike for higher fees by some of the younger members of the bar had produced a shortage of lawyers to represent indigent criminal defendants (pp. 19-20).

- The judge who presided at Miranda's trial, and who carefully described Arizona law on the use of confessions to the jury, telling them that they were not bound by his ruling that Miranda's confession was "voluntary," had a singularly portentous last name and an outlandish first name - Yale McFate (p. 23).

- Following the decision against him in the Arizona Supreme Court, Miranda sought review in the U.S. Supreme Court, but Alvin Moore declined to represent him any further, "citing a lack of funds and a lack of physical stamina" (p. 62). The head of the Phoenix chapter of the ACLU then turned to a young lawyer recently arrived from Washington, where he had clerked for Justice Byron White during the term Escobedo was decided (p. 62). ${ }^{22}$ Young Rex E. Lee wanted to accommodate the ACLU - he considered Miranda's case "the next big one . . . a reputation maker to end all reputation makers" (p. 62). But a Supreme Court rule prohibited its ex-clerks from practicing before it for two years. (In a decade and a half, however, $\mathrm{Mr}$. Lee would have more opportunities to appear before the Supreme Court than any lawyer could want.)

The ACLU turned next to John J. Flynn, a criminal law specialist and the chief trial attorney at Lewis \& Roca, one of Phoenix's largest and most respected law firms. Flynn in turn enlisted the aid of his law partner, former Yale law professor John P. Frank, the firm's principal appellate lawyer and a close student of the Supreme Court.23 The two lawyers "had barely begun work on the petition

21. Nevertheless, Ms. Baker tells us, Moore was considered "a cut above the average courtappointed lawyer." P. 20.

22. The ACLU had already gone to this young lawyer from time to time for advice on such matters as Supreme Court procedures. P. 62.

23. Ms. Baker informs us that the two lawyers "were a well-matched pair . . . perfectly complementary. Preparation of the case divided naturally: Fiynn, the trial attorney, a man of great personal charm and mental quickness, was to argue it before the Supreme Court; Frank, 
for cert," however, when they began to debate whether Miranda involved a violation of the fifth or the sixth amendment (p. 72). ${ }^{24}$

- Years later, in a self-deprecating talk at a federal judicial conference, John Flynn was to "take the rap" for focusing on the right to counsel in Miranda rather than on the privilege against compelled self-incrimination, ${ }^{25}$ but Baker reveals that Flynn believed that Miranda "really involved incrimination of oneself without the proper protections against compulsion" (p. 83). It was Frank, not Flynn, Baker tells us, who maintained that it was Miranda's right to counsel that had been denied (p. 72), and in the end "Flynn bowed to what he considered superior appellate wisdom and went along with Frank, who was also supported by two of their three assistants" (p. 83). ${ }^{26}$

- Since Miranda's confession to the police had been ruled inadmissible by the U.S. Supreme Court, a conviction at his retrial for kidnapping and rape "appeared impossible" (p. 192), but Miranda's

the scholar, articulate and thoughtful, was to assume the major burden of preparing the brief. They were assisted by several of the firm's younger attorneys." P. 63. Frank later estimated the cost of taking Miranda's case to the Supreme Court at " $\$ 50,000$ in office time alone, not counting travel time, printing of briefs, records and other expenses." P. 63.

24. According to Professor Bernard Schwartz, a similar debate over the grounds for reversing Miranda's conviction took place in the Supreme Court. Justice Douglas believed that the reversal should be based on the right to counsel and the interrogation by the police without offering counsel, but Justices Black and Brennan urged that the decision should turn on the fifth, rather than the sixth, amendment. See B. SCHWARTZ, supra note 20, at 590 . Moreover, according to Professor Schwartz, in response to a memorandum by Justice Brennan, the Chief Justice revised a draft of his opinion to emphasize that the case was concerned with procedures to effectuate the privilege against compelled self-incrimination. See id. at 590-92.

25. "[W]e agreed that the briefs should be written with the entire focus on the Sixth Amendment [right to counsel] because that is where the Court was headed . . . [but] in the very first paragraph [of the Miranda opinion] Chief Justice Warren said, 'It is the Fifth Amendment to the Constitution that is at issue today.' . . . That was Miranda's effective use of counsel." Flynn, Panel Discussion on the Exclusionary Rule, 61 F.R.D. 259, 278 (1973). These remarks are not mentioned by Ms. Baker.

26. John Frank's position was quite understandable. In the early and middle 1960's a goodly number of knowledgeable commentators voiced the fear or hope that the Supreme Court was closing in on the confession problem by projecting counsel (assigned as well as retained) into the station house and, perhaps, even extending it to police-citizen confrontations on the street. See, e.g., Barrett, Symposium on Poverty, Equality and the Administration of Criminal Justice, 54 KY. L.J. 464, 509 (1966) (6 months before Miranda); Fortas, The Consequences of Gideon, LEGAL AID BRIEF CASE, Oct. 1963, at 7, 8-9; Inbau, $A$ Fortum on the Interrogation of the Accused, 49 CORNELL L.Q. 382, 401 (1964) (5 months before Escobedo); Kuh, Symposium on Poverty, Equality and the Administration of Criminal Justice, 54 KY. L.J. 464, 499 (1966); Remarks of Louis H. Pollak, 43 A.L.I. Proc. 227-30 (1966) (one month before Miranda). And on the eve of Miranda four of the greatest judges of our time, who had taken to the lecture podium to comment on current (and imminent) developments in criminal procedure, addressed the police interrogation-confessions issue primarily in terms of when the right to counsel ought, or ought not, first "attach." See Breitel, Criminal Law and Equal Justice, 1966 UTAH L. REv. 1, 4-10, 17-18 (two months before Miranda); Friendly, The Bill of Rights as a Code of Criminal Procedure, 53 CALIF. L. REv. 929, 941-51 (1965); Schaefer, Symposium on Poverty, Equality and the Administration of Criminal Justice, 54 KY. L.J. 464, 521, 522-24 (1966) (6 months before Miranda); Traynor, The Devils of Due Process in Criminal Detection, Detention, and Trial, 33 U. CHI. L. REv. 657, 668-74 (1966) (two months before Miranda). 
overconfidence proved to be his downfall. Expecting that he would soon be released from prison following his acquittal at the second trial, Miranda had written to welfare authorities challenging the fitness of his common-law wife, Twila Hoffman, to have custody of their daughter. (Mrs. Hoffman had borne a child by another man while Miranda was behind bars.) Miranda's action so angered and frightened Mrs. Hoffman - if Miranda was released from prison, she feared, there was no telling what he might do to her - that she went to the prosecuting attorney and reported that at the county jail, shortly after his arrest, Miranda had confessed the kidnapping-rape to her (p. 192). ${ }^{27}$ Although John Flynn, who represented Miranda at his second trial, fought hard to suppress Mrs. Hoffman's surprise testimony, ${ }^{28}$ she was allowed to tell her story. The jury took less than an hour and a half to reconvict Miranda (p. 193).

- Gary Nelson, who had argued the Miranda case in the U.S. Supreme Court on behalf of Arizona, ran a "law and order" campaign for state attorney general in 1968 and won (pp. 259-60). Six years later he was appointed to the state court of appeals. In 1978, however, after two county bar associations had opposed his retention, Nelson was voted out of office. "Judge Sandra Day O'Connor, then of the Maricopa County Superior Court, was appointed to succeed him" (p. 384).

- Although Yale McFate, the presiding judge at Miranda's first trial, retired in 1979, he was frequently recalled to both the trial and appellate benches. In 1981, when Judge Sandra Day O'Connor was appointed to the U.S. Supreme Court, Judge McFate temporarily filled her position on the Arizona Court of Appeals (p. 384).

\section{III}

I have several quarrels with the generally carefully researched and carefully written Miranda: Crime, Law and Politics.

As Baker notes, in Gideon v. Wainwright, twenty-three state attorneys general filed an amicus brief in support of the defendant (p. 109), but in Miranda and its companion cases twenty-six state attorneys general joined New York's amicus brief, urging the Supreme Court to "go slow" and to allow procedural developments in the police interrogation-confessions area to take place in nonconstitutional

27. That Miranda's reconviction was based on a confession he made to his common-law wife is fairly well known. I was unaware, however, that Miranda's questioning of Mrs. Hoffman's fitness to have custody of their child impelled her to bring her story to the prosecutor.

28. Flynn argued both that Mrs. Hoffman's testimony was the "fruit of the poisonous tree" (according to Mrs. Hoffman, Miranda confessed to her only after she informed him that the police had told her about his confession to them) and that the testimony of a common-law wife was not admissible against her husband in Arizona. P. 193. 
terms. "The states," observes Baker, "had made a U-turn since Gideon" (p. 109). But that was not the case at all.

The state attorneys' general amicus brief in Gideon (hereinafter referred to as the Massachusetts-Minnesota brief) was not a spontaneous outpouring of support for a constitutional right to assigned counsel, but the product of long, hard work by two state attorneys general: Walter F. Mondale of Minnesota and Edward J. McCormack, Jr., of Massachusetts. ${ }^{29}$ They approached virtually every one of their counterparts and urged them to support Gideon's claim. Twenty-one states did, but, despite McCormack's and Mondale's popularity, charm and considerable powers of persuasion, about an equal number of states declined - among them California, New York and Pennsylvania. (I know that Mondale was especially disappointed that he could not persuade the Attorney General of New York, Louis Lefkowitz, to come aboard.)

Moreover, and more importantly for our purposes, those attorneys general who did join the Massachusetts-Minnesota brief did so on the understanding that the new constitutional right would operate prospectively only, would be limited to felony cases, and would not "attach" until the judicial process had begun.30 (The brief concluded by urging the Court to "require that all persons tried for a felony in state court" be afforded the right to counsel.31) Fred E. Inbau, the leading champion of police interrogation powers, would

29. I was teaching at the University of Minnesota Law School at the time and, so far as the Gideon case was concerned, was in fairly close touch with Attorney General Mondale and members of his staff. Richard Ervin, the Attorney General of Florida, where Gideon was incarcerated, wrote Mondale a routine letter, asking Mondale to join with him in the Gideon case. Mondale not only refused to do so, but wrote back that he would welcome the Supreme Court's imposition of a requirement of appointed counsel in all state felony cases. See letter from Walter F. Mondale to Richard W. Ervin (August 15, 1962) (on file with author). Mondale then began to phone or to write various state attorneys general, urging them to support Gideon's position. One of those whom Mondale contacted informed him that he had already been contacted by Attorney General McCormack for the same purpose. The two attorneys general formally joined forces. I believe that all, or virtually all, the attomeys general who agreed to file an amicus brief in support of Gideon did so without seeing any brief, because the brief was not written until the last minute. As Mondale and his staff, assisted by several members of the Minnesota law faculty, were about to start writing the amicus brief, Mondale learned that Gerald A. Berlin, an assistant attorney general of Massachusetts, assisted by about half a dozen Harvard law professors, was already writing a brief on behalf of Gideon. At this point Mondale and the state attorneys general he had recruited decided to sign the Massachusetts amicus brief. For a somewhat different but not inconsistent version of these events, see A. LEWIS, Gideon's TRUMPET 144-48 (1964).

30. See Brief for the State Governments, Amici Curiae, 2-3, 16, 21-23, Gideon v. Wainwright, 372 U.S. 335 (1963). The brief stressed that a criminal trial "is a highly complex, technical proceeding requiring representation by a trained legal adviser who can securely guide the accused through the maze of pitfalls into which he might otherwise stumble," Brief, supra, at 3, but "assum[ed] that the constitutional right to assigned counsel includes representation at the arraignment," where a defendant would need legal assistance in "how to plead and testify," Brief, supra, at $16 \&$ n.5.

31. Brief, supra note 30 , at $24-25$ (emphasis added). 
have had no diffculty signing the Massachussetts-Minnesota brief. ${ }^{32}$

That a substantial number of state attorneys general would urge the Court to expand the right to counsel in Gideon, but not a single one would urge the Court to adopt anything resembling the-Miranda warnings is hardly surprising. At the time of Gideon only a handful of states did not provide for the appointment of counsel in all felony cases as a matter of statute, court rule or general practice. ${ }^{33}$ At the time of Miranda, however, no police department anywhere regularly advised suspects of their fifth or sixth amendment rights before commencing "custodial interrogation." Moreover, as one reviewer of Gideon's Trumpet observed:

[W] hen that trumpet blows again, and again, when the Court provides new impetus for making [Gideon and Douglas v. California] more meaningful, not a few people who greeted the first call with applause will meet the second and the third with dismay.

.. . While we accept the Gideon and Douglas principles "in principle" - we are happy to appoint a lawyer to protect the record; we are delighted [as one colorfuI trial judge recently put it] to furnish the defendant a "pallbearer" - we hesitate to carry these principles to the point where they really bite, where a "criminal" may go free.

When the trumpet sounds again, we shall remember that too many people are roused by any "violation of the symbol of a ceremonial trial" but "left unmoved by an ordinary nonceremonial injustice." 34

The first blow against Miranda was struck by Harris $v$. New York, ${ }^{35}$ which held that statements preceded by defective warnings, and thus inadmissible to establish the prosecution's case in chief, could nevertheless be used to impeach the defendant's credibility.

32. See Inbau, Police Interrogation - A Practical Necessity, 52 J. CRIM. L., CRImINology \& Police ScI. 16, 19 (1961), reprinted in Police Power AND Individual Freedom 147, 150 (C. Sowle ed. 1962):

In my judgment the right to counsel at the time of trial or even at the very start of the judicial process, should be accorded and provided to all indigent defendants, insofar as practicable. . . even if [the case] amounts only to a misdemeanor. What I do object to is an extension of the right to arrestees, indigent or nonindigent, prior to the start of the judicial process. It is not constitutionally required, and practical consideratons will not tolerate such an extension. ...

33. See Kamisar, The Right to Counsel and the Fourteenth Amendment: A Dialogue on "the Most Pervasive Right" of an Accused, 30 U. CHI. L. Rev. 1, 17-20 (1962).

34. Kamisar, Book Review, 78 HARv. L. REv. 478, 489-90 (1964) (review of A. LewIS, supra note 29) (footnotes omitted). Douglas v. California, 372 U.S. 353 (1964), decided the same day as Gideon, held that fourteenth amendment equality requires a state to provide counsel for indigent defendants at least on their first appeal as of right. A decade later, the Court declined to apply Douglas to discretionary state appeals and applications for review in the Supreme Court, Ross v. Moffit, 417 U.S. 600 (1974).

35. 401 U.S. 222, 224 (1971). The Harris Court noted, but seemed untroubled by the fact, that some language in Miranda seemed to bar the use of statements obtained in violation of the landmark opinion for any purpose. For extensive discussion, and strong criticism, of Harris, see L. Levy, AGAINST THE LAW 149-63 (1974); Dershowitz \& Ely, Harris v. New York: Some Anxious Observations on the Candor and Logic of the Emerging Nixon Majority, 80 YALE L.J. 1198 (1971); Stone, The Miranda Doctrine in the Burger Court, 1977 Sup. Cr. REv. 99, 106-15. 
Baker does discuss Harris in considerable detail (pp. 313-18), but she fails to discuss Oregon v. Hass, ${ }^{36}$ a second "impeachment" case that inflicted a deeper wound on Miranda.

Since many suspects make incriminating statements even after the receipt of the Miranda warnings, Harris could have been explained, and contained, on the grounds that permitting impeachment use of statements acquired without complete or adequate warnings would not greatly encourage the police to violate Miranda. The somewhat increased probability of obtaining statements by not giving proper warnings, the argument runs, would not furnish the police much incentive to refuse to give the warnings, for such a refusal would prevent the use of any resulting statements in the prosecution's case in chief - and the police are likely to get statements even if they give the required warnings. But in Hass the police advised the suspect of his rights and he asserted them. Nevertheless, the police continued to question him. That such a flagrant violation of $\mathrm{Mi}$ randa should yield evidence that may be used for impeachment purposes, even if not for the government's case in chief, is especially troublesome because under these circumstances, unlike those in Harris, it is fair to assume that no hope of obtaining evidence usable for the case in chief operates to induce the police to honor Miranda. Hass, then, is a more dangerous decision than Harris. ${ }^{37}$

In Mincey v. Arizona, ${ }^{38}$ the Court did not find, as Baker asserts, that a statement taken from a seriously wounded man lying on his back in an intensive care unit violated Miranda (p. 395). Not even the Arizona trial court had the audacity to rule that the police had complied with Miranda in this case. At issue rather was whether the statements were "voluntary" and thus admissible for impeachment purposes despite being obtained in violation of Miranda.

Writing on pieces of paper provided by the hospital (he was unable to speak because of the tube in his mouth), the suspect repeatedly expressed his wish not to be questioned, but a detective continued to interrogate him. Nevertheless, the trial court found "with unmistakable clarity" that the statements were "voluntary" and the state supreme court unanimously affirmed. On the basis of

36. 420 U.S. 714 (1975).

37. Even more disturbing than Harris and Hass is the Court's recent extension of them to permit the use of a defendant's prior silence to impeach his credibility when he chooses to take the stand in his own defense. Thus, in Jenkins v. Anderson, 447 U.S. 231 (1980), the Court held that a murder defendant's testimony that he acted in self-defense could be impeached by the fact that he did not go to the authorities and report his involvement in the stabbing. In Fletcher v. Weir, 455 U.S. 603 (1982) (per curiam), the Court held that even a defendant's post-arrest silence - so long as he was not given the Miranda warnings - could be used to impeach him if he took the stand.

38. 437 U.S. 385 (1978). 
its independent evaluation of the record, the Supreme Court found the statements "involuntary." Only Justice Rehnquist dissented. As was true in many of the pre-Miranda voluntariness cases, the dissent disputed the majority's reading of the record. I venture to say that the Mincey case may have cooled more than one Justice's ardor for the pre-Miranda "voluntariness" test.

I share Baker's view that, although it hardly escaped the 1970's unscathed, Miranda weathered the storm of the first decade of the Burger Court and now appears more secure than it has at any time since the days of Harris and Hass. ${ }^{39}$ But Baker thinks the turning point was the 1977 "Christian burial speech" case, Brewer v. Williams ${ }^{40}$ (a case she discusses in considerable detail (pp. 389-95)). I disagree. I think it was the 1980 case of Rhode Island $v$. Innis, ${ }^{41}$ a case Baker does not discuss at all. 42

In Williams, as Baker notes, twenty-one state attorneys general did urge the Court, without success, to overrule Miranda (p. 389). ${ }^{43}$

39. See Kamisar, The Warren Court (Was It Really So Defense-Minded?), the Burger Court (Is It Really so Prosecution-Oriented?) and Police Investigatory Practices, in THE BURGer Court: The Counter-Revolution that WASN'T 62, 88-91 (V. Blasi ed. 1983) (reviewed in this issue).

40. 430 U.S. 387 (1977). Williams, suspected of murdering a young girl in Des Moines, Iowa, surrendered himself to the Davenport, Iowa, police. Captain Leaming and another Des Moines detective went to Davenport to pick up Williams and drive him back to Des Moines (some 160 miles away). By the time the two Des Moines officers arrived in Davenport, adversary judicial proceedings had already commenced against Williams and he had already retained counsel. On the return trip, admittedly in an effort to induce Williams to reveal the location of the girl's body, Captain Leaming delivered to Williams what has come to be known as the "Christian burial speech": "[Y]ou yourself are the only person that knows where this little girl's body is. . . . I feel that [the parents] should be entitled to a Christian burial for their little girl [and that] we should stop and locate [the body] on the way [back to Des Moines]." 430 U.S. at 392-93.

Although neither the Supreme Court nor the other courts that had mulled over the Christian burial speech seems to have been aware of it, the police captain who rendered the "speech" had given one version of it at a pretrial hearing and, in my view, a significantly different version at the trial itself. The latter version was the only one quoted and discussed by the Supreme Court and the lower federal courts. See generally KAMISAR EsSAYS, supra note 16, at 113-37. Williams was retried and reconvicted and the case has now returned to the Supreme Court. See Williams v. Nix, 700 F.2d 1164 (8th Cir.), cert. granted, 103 S. Ct. 2427 (1983). For an incisive treatment of the "fruit of the poisonous tree" problems raised by the second Williams case, see Johnson, The Return of the "Christian Burial Speech" Case, 32 EMORY L.J. 349 (1983).

41. 446 U.S. 291 (1980), thoughtfully discussed in W. White, Interrogation Without Questions: Rhode Island v. Innis and United States v. Henry, 78 МicH. L. REv. 1209 (1980).

42. Ms. Baker does quote one sentence from Chief Justice Burger's concurrence in Innis (stating that he is not (no longer?) disposed to overrule Miranda "at this late date"), but she does not identify the Innis case by name. P. 396.

43. As my colleague, Jerold Israel, has pointed out, these states did not request that " $M i$ randa be overruled in the sense that Miranda warnings no longer be required, but overruled only in the sense that a Miranda violation no longer require automatic exclusion of evidence." Israel, Criminal Procedure, the Burger Court, and the Legacy of the Warren Court, $75 \mathrm{MICH} . \mathrm{L}$. REV. 1319,1382 n.270 (1977). 
But as Baker herself points out, the Court saw no need to consider the applicability of Miranda and decided the case solely on Massiah sixth amendment grounds (p. 392). Thus, at the time it was handed down, Williams demonstrated only that Williams' able court-appointed counsel, Professor Robert Bartels, had shown considerable acumen in stressing that Williams was a sixth amendment-Massiah case and not that his fears that the two Miranda dissenters still on the Court and three or more of the new appointees might join to overrule Miranda (p. 391) were unfounded.

Once the Williams Court chose to decide the case on the basis of the Massiah doctrine, whether the "Christian burial speech" constituted interrogation within the meaning of Miranda became, or should have become, constitutionally irrelevant. ${ }^{44}$ Nevertheless, the Williams majority evidently thought it desirable, if not necessary to classify the "speech" as a form of interrogation or "tantamount" to interrogation 45 - and all four dissenting justices insisted it was not. But, if the "speech" did amount to "custodial interrogation," then the Miranda route to decision seemed no less inviting than the one Massiah provided. Under the circumstances of the case - Williams had asserted both his right to counsel and his right to remain silent several times earlier that day and the "speech" had not been preceded by a new set of warnings - the speech appeared to have been delivered in clear violation of Miranda. Thus the Williams Court's avoidance of Miranda seemed "at least puzzling and at worst (for supporters of Miranda, at any rate) downright ominous."46

As I see it, it was Rhode Island v. Innis, not Williams, that

44. In Massiah, nothing turned on whether the defendant was "interrogated" (as that term is normally used). Indeed, there is no indication that the "secret government agent" who dealt with Massiah "questioned" him or that he was instructed to do so. Nor was Massiah "in custody" when he made damaging admissions. He was out on bail and he assumed that he was simply talking to a friend, his partner in crime, who had also been indicted. The Massiah doctrine prevents the government from eliciting or inducing incriminating statements from one against whom adversary judicial proceedings have begun, whether or not he is "in custody," whether or not he is "interrogated," and whether or not he is even aware that he is dealing with a government agent. See KAMISAR ESSAYS, supra note 16, at 169-88.

- 45. See Williams, 430 U.S. at 399-400.

46. KAMISAR EsSAYS, supra note 16, at 202. Schulhofer, Confessions and the Court (Book Review), 79 MICH. L. REv. 865, 887 (1981) (reviewing KAMISAR ESSAYs) suggests a "plausible (and potentially 'ominous') reason ... . for the Court's preference for the Massiah route in Williams" that I had not considered. Williams reached the Court in the context of a federal habeas corpus proceedings eight months after the Court ruled in Stone v. Powell, 428 U.S. 465 (1976), that a state prisoner may not be granted federal habeas corpus relief on search and seizure grounds unless he has been denied an opportunity for full and fair litigation of the claim in the state court. Miranda claims, maintains Schulhofer, seem much closer to search and seizure claims for purposes of applying Stone than Massiah claims. See Schulhofer, supra, at 890 . "[I]t seems reasonable to speculate that at least some members of the [Willioms] Court would have had difficulty ignoring Stone's implicatons, if reliance had been placed on Miranda. The Court's decision in Williams to avoid that route could then be read as darkening the shadow cast by Stone over the continued availability of Miranda claims on habeas." Id. at 887 (footnote omitted). 
demonstrated "Miranda was not dead yet. . . . Not by a long shot" (p. 389). Against a background of such cases as Harris and Hass, ${ }^{47}$ supporters of Miranda awaited the decision in Innis with trepidation. Innis had been convicted, and seemed plainly guilty, of heinous crimes: the kidnapping, robbery, and murder of a cabdriver (by a shotgun blast to the back of the head). He had made incriminating statements while being driven to a nearby police station, only a few minutes after being placed in a police vehicle, and any "interrogation" that might have occurred in the vehicle was very brief and quite mild 48 - a far cry from the persistent station-house questioning that had taken place in Miranda and its companion cases. Moreover, if any "interrogation" had occurred in Innis it had been conducted by "street cops," not detectives skilled in the art of inducing people to confess. In short, Innis looked like "a godsend for $M i$ randa critics."49

The Innis Court might have limited Miranda to station-house interrogation or its equivalent (for example, the five-hour ride in a police vehicle that occurred in Williams). But it did not. The Court might have taken a mechanical approach to "interrogation" and limited it to instances where the police directly address a suspect. Again it did not. The Court might have limited interrogation to situations where the record establishes that the police intended to elicit a response (the Innis record did not), an obviously difficult test to administer. It did not do this either.

Instead, the Court held that "Miranda safeguards come into play whenever a person in custody is subjected to either express questioning or its functional equivalent," 50 that is, "interrogation" includes "any words or actions on the part of the police (other than those normally attendant to arrest and custody) that the police should know are reasonably likely to elicit an incriminating response from the suspect."s1 Although the Innis case involved police "speech," the Court's definition embraces police tactics that do not. Thus, the Court seems to have repudiated the position taken by a number of lower courts that confronting a suspect with physical evidence or with an effusive accomplice is not interrogation because it does not

47. See also Oregon v. Mathiason, 429 U.S. 492 (1977) (per curiam) (discussed by Baker at pages 391-92); Michigan v, Tucker, 417 U.S. 433 (1974) (discussed by Baker at pages 349-50). For in-depth analyses of Harris, Hass, Tucker, Mathiason, and other "Burger Court" Miranda cases, see Stone, The Miranda Doctrine in the Burger Court, 1977 Sup. CT. REv. 99.

48. Two officers conversing with each other, but in Innis's presence, expressed concern that because the murder had occurred in the vicinity of a school for handicapped children, one of them might find the missing shotgun and injure himself. At this point Innis interrupted the officers and offered to lead them to the spot where the shotgun was hidden.

49. Grano, Rhode Island v. Innis: A Need to Reconsider the Constitutional Premises Underlying the Law of Confessions, 17 AM. CRIM. L. REv. 1, 1 (1979).

50. 446 U.S. at 300-01.

51. 446 U.S. at 301 (footnotes omitted). 
entail verbal conduct on the part of the police. 52

One may criticize the wording of the Innis Court's test, as Justice Stevens did in an insightful dissent. Justice Stewart, the author of the Innis opinion, might have articulated more clearly what I think he meant: that "interrogation" embraces any police conduct that would normally be understood as calling for a response about the substance of a case or that has the same force and effect as a substantive question. 53

One has even more cause to quarrel, as the three dissenters did and I would, with the Court's application of its definition of interrogation to the Innis facts; it held that the defendant had not been subjected to the "functional equivalent" of questioning. But Innis is a more difficult case than most are likely to be because there was "a basis for concluding that the officers' remarks were made for some purpose other than that of obtaining evidence from the suspect."54 Although I for one would not have so concluded, "[a]n objective listener could plausibly conclude that the policemen's remarks in Innis were made solely to express their genuine concern about the danger posed by the hidden shotgun"ss and thus not view their conversation "as a demand for information." 56

Considering the various ways in which the Innis Court could have cut down the meaning and scope of Miranda, its rather generous definition of "interrogation" seems a good deal more significant than its questionable application of the definition to the peculiar facts before it. In Innis, I think, the process of qualifying, limiting and shrinking Miranda came to a halt (although it remains to be seen whether it is only a temporary hiatus). Indeed, it seems fair to say that in Miranda's hour of peril, the Innis Court rose to its defense. 57

52. See KaMISAR EsSAYS, supra note 16, at 156-58 n.21.

53. For an extensive discussion of the Innis Court's definition of "interrogation" see W. White, supra note 41, at 1224-36; see also Kamisar, Police Interrogation and Confession, in $2 \mathrm{~J}$. Choper, Y. Kamisar \& L. Tribe, The Supreme Court: Trends and Developments 1979-80 83, 88-97 (1981).

54. W. White, supra note 41 , at $1234-35$ (emphasis in original).

55. Id. at 1235 (emphasis added).

56. $I d$.

57. If Innis encouraged Miranda's defenders, Edwards v. Arizona, 451 U.S. 477 (1981), gladdened them even more. Although Ms. Baker devotes only a few lines to the majority opinion in Edwards and does not identify it by name, p. 395, the case "provided the Burger Court's first clear-cut victory for Miranda." Sonenshein, Miranda and the Burger Court: Trends and Countertrends, 13 LOY. U. CHI. L.J. 405, 447 (1982).

Sharply distinguishing Michigan.v. Mosley, 423 U.S. 96 (1975), Edwards held that when a suspect invokes his right to counsel (as opposed to his right to remain silent, the right asserted in Mosely), the police cannot "try again." Under these circumstances, a valid waiver of the right to counsel cannot be established by showing "only that [the suspect] responded to further police-initiated custodial interrogation," even though he is again advised of his rights at a second interrogation session. 451 U.S. at 484 . The suspect cannot be questioned anew "umtil 
IV

Pointing to the few courses in criminal law offered at the time, compared to the many in property law, Baker would have us believe that in the 1960's, when the Warren Court was "taking a hard look" at criminal procedure and "thereby fomenting a revolution in the criminal law" (p. 19), the law schools were still neglecting this area. This state of affairs, we are told, reflected attitudes of faculty members and curriculum planners "trained in the same system" - criminal law had been neglected since the late eighteenth century, when the first American law school had been established - "making it a triumph in self-perpetuation" (p. 19)..$^{58}$

I suspect that Baker's view is widely held. Over the years, more lawyers, judges, students, and young colleagues than I care to remember have commiserated with me on learning that when I started teaching in the fall of 1957 I was assigned criminal law and procedure. How dull and dreary it must have been teaching criminal law and procedure in those days, these people comment sadly, in the days before the Warren Court began handing down the opinions that today one considers distinctive of that Court. These people always seem surprised, and perhaps a bit disappointed, when I insist that it was not that way at all.

It was not dull or dreary because a remarkable group of law teachers had preceded me to academe - such people as Francis Allen, Edward Barrett, Albert Beisel, Caleb Foote, Sanford Kadish, Charles McCormick, Bernard Meltzer and Monrad Paulsen. ${ }^{59}$ They,

counsel has been made available to him, unless [he] himself initiates further communication, exchanges or conversation with the police." 451 U.S. at 484-85 (emphasis added).

Edwards reinvigorates Miranda in an important respect, but what the Court giveth the Court may taketh away. Oregon v. Bradshaw, 103 S. Ct. 2830 (1983), a case handed down since the publication of Ms. Baker's book, interprets "initiation [of] further communication" so broadly (Bradshaw was held to have "initiated" a conversation with an officer within the meaning of $E d w a r d s$ when, shortly after being handcuffed, he asked, "Well, what is going to happen to me now?") that it seems to sap Edwards of much of its vitality.

58. A look at the law school curricula of the late 1950's and early 1960's is likely to be misleading, for much of what is now taught in separate courses on criminal procedure was then taught in the course on evidence. Indeed, the evidence teachers, for example, Maguire, McCormick, Meltzer and Morgan, made great contributions to the "criminal procedure" literature. See notes 59 \& 60 infra. Moreover, at least some of what is now taught in a typical criminal procedure course was then taught in constitutional law or in first-year criminal law.

59. See A. Beisel, Control Over Illegal Enforcement of the Criminal Law: Role of THE Supreme Court (1955); C. MCCormick, HaNdbook of THE LaW of EviDENCE (1st ed. 1954) (chs. 8, 12, 13 \& 14); Allen, The Wolf Case: Search and Seizure, Federalism and the Civil Liberties, 45 ILL. L. REv. 1 (1950); Allen, Due Process and State Criminal Procedures: Another Look, 48 Nw. U. L. Rev. 16 (1953); Barrett, Exclusion of Evidence Obtained by Illegal Searches and Seizures - A Comment on People v. Cahan, 43 CALIF. L. Rev. 565 (1955); Dession, The New Federal Rules of Criminal Procedure, 55 YALE L.J. 694 (1946); Donnelly, Judicial Control of Informants, Spies, Stool Pigeons, and Agents Provocateurs, 60 YALE L.J. 1091 (1951); Donnelly, Comments and Caveats on the Wire Tapping Controversy, 63 YALE L.J. 799 (1954); Foote, Tort Remedies for Police Violations of Individual Rights, 39 MINN. L. REv. 493 (1955); Foote, Vagrancy-Type Law and Its Aministration, 104 U. PA. L. Rev. 603 
no less than the Justices (and, I venture to say, before some of the Justices had gotten around to it) were "taking a hard look" at constitutional criminal procedure. If their predecessors had been indifferent to, or complacent about, the administration of criminal justice, it could hardly be said that they were perpetuating such attitudes.

Teaching criminal procedure in the pre-Mapp, pre-Miranda days was anything but dull. The aforementioned law professors continued to write insightful and provocative articles and others soon joined them..$^{60}$ Moreover, the American Bar Foundation's Survey of

(1956); Foote, Safeguards in the Law of Arrest, 52 Nw. U. L. REv. 16 (1957); Hall, The Law of Arrest in Relation to Contemporary Social Problems, 3 U. CHI. L. Rev. 345 (1936); Hall, Police and Law in a Democratic Society, 28 IND. L.J. 133 (1953); Inbau, The Confession Dilemma in the United States Supreme Court, 43 ILL. L. REv. 442 (1948); Inbau, Restrictions in the Law of Interrogation and Confessions, 52 Nw. U. L. REv. 77 (1957); Kadish, Methodology and Criteria in Due Process Adjudication - A Survey and Criticism, 66 YALE L.J. 319 (1957); McCormick, The Scope of Privilege in the Law of Evidence, 16 TEXAS L. REV. 447 (1938); McCormick, Some Problems and Developments in the Admissibility of Confessions, 24 TEXAs L. REv. 239 (1946); Meltzer, Involuntary Confessions: The Allocation of Responsibility between Judge and Jury, 21 U. CHI. L. REv. 317 (1954); Miller, The Supreme Court's Review of Hypothetical Alternatives in a State Confession Case, 5 Syracuse L. Rev. 53 (1953); Morgan, The Privilege Against SelfIncrimination, 34 MINN. L. REV. 1 (1949); Paulsen, The Fourteenth Amendment and the Third Degree, 6 STAN. L. Rev. 411 (1954); Paulsen, Safeguards in the Law of Search and Seizure, 52 Nw. U. L. Rev. 65 (1957); Pollak, Proposals to Curtail Federal Habeas Corpus for State Prisoners: Collateral Attack on the Great Writ, 66 YALE L.J. 50 (1956); Pollak, Mr. Justice Frankfurter: Judgment and the Fourteenth Amendment, 67 YALE L.J. 304 (1957); Reynard, Freedom from Unreasonable Search and Seizure - A Second Class Constitutional Right?, 25 IND. L.J. 259 (1950); L.B. Schwartz, On Current Proposals to Legalize Wire Tapping, 103 U. PA. L. REV. 157 (1954); Scott, Federal Restrictions on Evidence in State Criminal Cases, 34 MiNN. L. REv. 489 (1950); Scott, Federal Control Over Use of Coerced Confessions in State Criminal Cases Some Unsettled Problems, 29 IND. L.J. 151 (1954); Waite, Police Regulation by Rules of Evidence, 42 MiCH. L. REv. 679 (1944); Waite, Judges and the Crime Burden, 54 MicH. L. REv. 169 (1955).

Although, so far as I know, Dean Erwin Griswold never taught courses directly bearing on the subject, no list of the constitutional criminal procedure literature of the period would be complete if it failed to mention E. GRISwOLd, THE FIFTH AMENDMENT TODAY (1955). See also Griswold, The Fifth Amendment Today, 39 MARQ. L. REv. 191 (1956). Moreover, during this period, various political science professors also made important contributions to the constitutional criminal procedure literature. See, e.g., W. Beaney, The Right to Counsel in AMERICAN COURTS (1955); Fellman, The Federal Right to Counsel in State Courts, 31 NEB. L. REv. 15 (1951); Fellman, The Right to Counsel Under State Law, 1955 WIS. L. REv. 281; Grant, Circumventing the Fourth Amendment, 14 S. CAL. L. REv. 359 (1941); Grant, Federalism and Self-Incrimination, 4 UCLA L. Rev. 549 (1957); Westin, The Wire-Tapping Problem: An Analysis and a Legislative Proposal, 52 Colum. L. REV. 165 (1952).

60. See, e.g., J. Maguire, Evidence of Guilt (1959); R. Moreland, Modern CrimiNAL Procedure (1959); Allen, The Supreme Court, Federalism, and State Systems of Criminal Justice, 8 DE PAul L. Rev. 213 (1959); Barrett, Personal Rights, Property Rights, and the Fourth Amendment, 1960 SuP. CT. REv. 46; Foote, The Fourth Amendment: Obstacle or Necessity in the Law of Arrest?, 51 J. CRIM. L., CRiminology \& Police Scl. 402 (1960); A. Goldstein, The State and the Accused: Balance of Advantage in Criminal Procedure, 69 YALE L.J. 1149 (1960); J. Goldstein, Police Discretion Not to Invoke the Criminal Process: Low-Visibility Decisions in the Administration of Justice, 69 YALE L.J. 543 (1960); Hogan \& Snee, The McNabb-Mallory Rule: Its Rise, Rationale and Rescue, 47 Geo. L.J. 1 (1958); Kadish, The Advocate and the Expert - Counsel in the Peno-Correctional Process, 45 MINN. L. REv. 803 (1961); Remington, The Law Relating to "On the Street" Detention, Questioning and Frisking of Suspected Persons and Police Arrest Privileges in General, 51 J. CRIM. L., CRIMINology \& POLICE ScI. 386 (1960). 
the Administration of Criminal Justice project (directed by Professor Frank Remington), had completed its field studies the summer before I entered the teaching ranks, and a seven-volume mimeographed Pilot Project Report, summarizing the project's 2,000 "field reports" and other material, was soon circulating widely among law professors. ${ }^{61}$ And before the Warren Court's "revolution in criminal procedure" had really been launched, a number of important papers had been delivered at a four-part International Conference in Criminal Law Administration held at the Northwestern University School of Law (a conference planned and directed by Professor Fred Inbau). ${ }^{62}$

The judicial philosophy expressed in Mapp, Miranda, and other Warren Court cases "did not spring from the head of Zeus one morning." 63 The so-called revolution in criminal procedure "has both prologue and epilogue." 64 No doubt Justices Black, Douglas and others, whose views on constitutional criminal procedure did not often command a majority until the 1960's, contributed significantly to this "prologue." No doubt the views they advanced, although often in dissent, had a significant impact on many law professors. ${ }^{65}$ But I like to think, and there is reason to think, that it was a two-way street - that the professors were also influencing the Justices and helping to write some of the "prologue." Allen, Foote, Paulsen and other commentators of the early Warren Court and pre-Warren

61. See the preface to W. LAFave, ARrest: The Decision to Take a Suspect into Custody ix (1965).

62. The papers delivered by the Conference participants were first published in various 1960 and 1961 issues of the Journal of Criminal Law, Criminology and Police Science and then reprinted under one cover in Police POWER AND INDIVIdUAL FreedoM, supra note 32. See the Introduction to this volume by Professor Claude Sowle.

63. Pye, The Warren Court and Criminal Procedure, 67 Mich. L. REv. 249, 254 (1968).

64. Allen, The Judicial Quest for Penal Justice: The Warren Court and the Criminal Cases, 1975 U. ILL. L.F. 518, 521. Indeed, the effort to estabish constitutional minima for state systems of criminal justice "had constituted a major concern of the Court for 30 years before Earl Warren took the oath as Chief Justice." Id.

65. I think it fair to say that Justice Frankfurter had a considerable influence on "judicial activists" in academe as well as judicial passivists. Some may only remember him in the search and seizure area as the Justice who wrote the opinion declining to impose the exclusionary rule on the state courts as a matter of fourteenth amendment due process, Wolf v. Colorado, 338 U.S. 25 (1949), but I can think of no person, on or off the Court, who has underscored the importance of the fourth amendment more forcefully and more eloquently than did Frankfurter in his dissenting opinions in two federal search and seizure cases. See United States v. Rabinowitz, 339 U.S. 56, 70 (1950); Harris v United States, 331 U.S. 145, 157 (1947). As for police interrogations and confessions, Justice Frankfurter did join the dissent in Ashcraft v. Tennessee, 322 U.S. 143 (1944) (the majority, per Black, J., ruled that the confession was the product of "inherently coercive" conditions), but he soon became the leading exponent of the "police conduct" or "police methods" rationale for barring the use of confessions. According to this rationale, in order to condemn (and, hopefully, to deter) objectionable police interrogation methods, confessions produced by such methods must be excluded regardless of how relevant and credible they might be. See Rogers v. Richmond, 365 U.S. 534, 54041 (1961); Rochin v. California, 342 U.S. 165, 172-74 (1952); Watts v. Indiana, 338 U.S. 49, 50 n.2, 55 (1949). 
Court years were, in their own way, also "fomenting a revolution in the criminal law."

Those who doubt that the law professors of old contributed significantly to the thinking of the Warren Court - the Court that found, for example, that the privilege against self-incrimination was "at issue" in confession cases - ought to consider the following:

It well may be that the adherence of the courts to [the] statement of the confession-rule in terms of "voluntariness" is prompted not only by a liking for its convenient brevity, but also by a recognition that there is an interest here to be protected closely akin to the interest of a witness or of an accused person which is protected by the privilege against compulsory self-crimination.

It may be conceded that in time of origin the confession-rule and the self-crimination rule were widely separated. . . . Nevertheless, the kinship of the two rules is too apparent for denial. It is significant that the shadow of the rack and the thumbscrew was part of the background from which each rule emerged. . . .

. . . Such policy as modern writers are able to discover as a basis for the self-crimination privilege - and it is feeble and inadequate at best - pales to a flicker beside the flaming demands of justice and humanity for protection against extorted confessions. ${ }^{66}$

Professor Charles McCormick wrote this a long time ago when the "voluntariness" test was no more than a shorthand statement of the rule that a confession was admissible as long as it was free of influences that made it untrustworthy - when Earl Warren was running for attorney general of California - and when Ernest Miranda had not yet been born.

66. McCormick, The Scope of Privilege in the Law of Evidence, 16 TEXAs L. REv. 447, 45255 (1938). 